\title{
An Ethnomethodological Perspective on the Conflict between Magistrates and Journalists in Cameroon
}

\author{
Jean-François Nguegan, Thomas Essono \\ University of Yaoundé II, Advance School of Mass Communication (ASMAC), Yaoundé, Cameroon \\ Email:ngueganfj@yahoo.fr, t.essono@gmail.com
}

Received 2 October 2015; accepted 24 December 2015; published 30 December 2015

Copyright (C) 2015 by authors and Scientific Research Publishing Inc.

This work is licensed under the Creative Commons Attribution International License (CC BY). http://creativecommons.org/licenses/by/4.0/

(c) (i) Open Access

\begin{abstract}
The report of the magistrate profession to that of a journalist in Cameroon can be studied from the perspective both of the sociology of professions and sociology of the conflict; the actors, who belong to different territories, are usually against the quality, legitimacy and competence required to deal with media information, and judicial control, individual freedom. This relationship is mainly studied in this research in terms of symbolic interactionism, to emphasize first of all on the importance that judges and journalists themselves give to their profession and secondly on the rationality of their game in the construction and the demarcation of their respective territories. This article is a contribution to the study of the discourse of these two groups of professionals who compete with each other.
\end{abstract}

\section{Keywords}

Logic of Actors, Media Power, Conflict, Ethnomethodology, Territories

\section{Introduction}

The opposition between magistrates and journalists in Cameroon can be seen in the mobilization of these actors that protect their respective interests, maximizing their strategic gains while minimizing their losses when wearing blows with their opponents, reciprocally (Ebert, 1993). Relations between the actors of these two professions are included within the explanation of the concept gives by Lester (1980) and Cabin (2000) who drew their inspiration from George Herbert Mead (1934), the socio-psychologist. Namely, the social fact is not a given but a process that is built through concrete situations. Social fact, they say, is the dynamics of exchange, and it is through the meaning that individuals give to their action, that the essence of the social game can be captured.

How to cite this paper: Nguegan, J.-F., \& Essono, T. (2015). An Ethnomethodological Perspective on the Conflict between Magistrates and Journalists in Cameroon. Advances in Journalism and Communication, 3, 115-122.

http://dx.doi.org/10.4236/ajc.2015.34013 
Socio-political life is a behavioral system which is different from the environment in which it is located and is open to its influences (Mattelart \& Mattelart, 2010). And the ability of the system to master social tension depends, they say, on the presence and nature of the information that is returned to the actors and decision makers. Freund (2003) meanwhile clearly raises the conflict as the most relevant analyst of modern societies.

We consider studying these relationships in the ethno methodological perspective then we will return to analyze how actors of both professions come into contact, inaugurate, maintain and finally conclude exchange sequences and the consequences of these exchanges on social change as it could be considered in the long term. It is a relationship combining a reaffirmation of identity and mobilization of strategic allies, bilateral or crossed, structured around the political game.

We assume, in view of these premises, the existence of a conflict between judges and journalists, and, in this article, the first in a series of two, we indicate the scope of the study (I); proceed to the construction of the object of study (II); state the research methodology (III); and briefly discuss hypotheses and partial conclusions, which in this article, are still only programmatic (IV).

\section{Research Objective}

A study of the relationship between judges and journalists in Cameroon tends to prove that the media, in Africa, too, become like in the West, where previous studies have revealed, and even resolved most social conflicts; and, therefore, over determine the game of the actors in the political public sphere. It addresses the dynamics of exchange between the actors and questions the social representations over the meaning of these exchanges (Boyomo, 1996, 1999). It intends to check and establish the fact that the public media space provides a relevant frame of reference for social change.

\subsection{The Scope of the Study}

The scope of this research is linked both to its theoretical framework and its trans-disciplinary anchorage.

\subsubsection{The Theoretical Framework}

The public space is a production device of choice for social actors in the sense of Habermas (1981), Foucault (1975) or Bourdieu (1980). It postulates inter-subjectivity. Individuals, out of their private sphere, come into relationship with each other and express on a daily basis, usually divergent views on all sorts of subjects, because unanimity is rare, and consensus is built on tensions and interests defined, quantified and traded.

The inclusion of social representations makes this research more complex and juridicist. The bonds of social representation are programmatic and preparatory (Moscovici \& Vignaux, 2000) in their psycho sociological approach:

“If a social representation is a 'preparation for action', it is not only insofar as it guides the behavior, but especially in so far as it reshapes and constitutes the elements of the environment where it is to take place”.

For these authors, social representations thus determine the possible communications field, and the values or ideas present in the visions shared by the groups. The socio-professional conflicts between the magistrates and the journalists in Cameroon, has been rendered more complex by an almost infinite perspective of identical profiles difficult to analyze, because this country has 275 languages. For some pending court cases, the socio-political environment leaves us to subsume that a bamileke journalist would out rightly criticize the instructions or proceedings of a journalist or bulu magistrate if his judgement condemns a bamileke defendant like Yves Michel Fotso. These professionals are the elites that can rank among the dominant players and who according to Guy Rocher, affect social change:

"The elite includes individuals and groups who, because of the power they hold, or their influence, contribute to the historic action of a community".

In the public space, in fact, four major types of speech claim, to hold the dominant discourse on specific issues: they are the speeches of politicians, journalists, intellectuals, and those of socio-professional actors. This is the discourse on professional practices of the judiciary and those of journalists, practices on civil liberties, justice and political governance. 


\subsubsection{The Legal and Sociological Basis}

This research is transcendental because it is situated at the edge of sociology of law and political science. In their relations with journalists, magistrates act in the political public sphere, through government and public action, based on the monopoly of legitimate violence of the State from which they proceed constitutionally; and anticipate from journalists, a predominance of the latter, actors of power that was simply instituted, they argue them and even challenge them.

The study of urban dynamics has shown that ethnicity has gradually given way to corporatism, but has not totally disappeared. So the conflict between judges and journalists is not totally devoid of tribalistic threats when the sociology of the actor's name is used, in a cyclical manner in the judicial investigation and consequently on how journalists report judicial decisions.

This research which addresses the concepts of public space, the state, professions; and paradigms of mediation, conflict, and information; therefore, has as base a strong sociological and legal anchorage before being focused on the specific field of information and communication.

Journalists, meanwhile, have camped their action in the public media space of which they have the monopoly of expertise and control. The magistrates are forced to join them in an attempt to regain the initiative of organized action around the crystallization of public opinion. The latter has become a major challenge for the society in the 21st century whose most significant determinants are information and communication.

The Universal Declaration of Human Rights explicitly proclaims two great truths:

- Men are born equal.

- Men have the right to freedom of speech, conscience and worship, information and communication.

The preamble to the Universal Declaration of Human Rights emphasizes the ideal of equal inalienable rights of freedom and of justice based on the dignity of the members of the human family. It emphasizes at the same time, on the urgent need that human rights should be protected by the rule of law, a democratic regime, so that man is not forced, as a last resort, to rebellion against tyranny and oppression.

The African Charter of Human Rights exists. It supervises and organizes the freedom of individuals and peoples, modeled on European or universal instruments in this area.

National texts also exist. The law 90/052 of 19 December 1990 on freedom of social communication, the decree of 1996, which formally abolished censorship on the one hand and on the other, that of 3 April 2000 on the liberalization of the audiovisual sector in Cameroon have increased the symbolic and strategic capital of a profession, that of journalists, actors in the social representations here are seen as fearless and unrepentant whistleblowers. The unveiling of hidden facts or phenomena, combines with their tribune of functions and role is universally recognized to contribute to research and to the manifestation of the truth.

It is with regards to these principles that journalists and judges, both fully exercise their functions with the understanding that only the magistrate has the prerogative to evaluate breaches of criminal law and obtain eventual imprisonment to all citizens including journalists.

\subsubsection{Information and Communication}

Relations between judges and journalists are built on the basis of this unavoidable fact, the entire society, like any organization, is a group of people living together in a space, having a goal or a common destiny and empowering themselves to achieve it. It is an association between individuals who must overcome the individual interests. No society can function without this organic link that connects individuals into a greater whole. Somehow, communication refers to how each social actor relates with the other.

Information Communication Sciences is interested in the identities and profiles of the actors, as it analyses the names, languages, status, territories and the search for meaning in these actors. The role and challenges of journalism and the media can be found in international texts, those of UNESCO, the African region, and those of national laws regulating the practice of this profession and therefore reflecting the interest that the creation and use of the media have for States and the international community.

Freedom of communication is, according to UNESCO, the essential means of disseminating knowledge and values. Its main function in democratic societies is to enable citizens to express themselves and be heard, and therefore hope to influence social policy. These texts, especially those of the years 1989 to 1995, were aimed at the promotion of independent and pluralistic media in particular, and cooperation between private African newspapers, with the idea to help them exchange their publications and information.

The action of UNESCO for the promotion of press freedom in the world is clearly expressed in Resolution 4.3 
adopted by the General Conference at its 26th session in 1991.

\subsection{Construction of the Research Objective}

\subsubsection{Construction of the Objective}

Reports and commentaries from journalists on pending cases before the courts are governed by a strict legal and regulatory framework that journalists regard as a humiliation, a restriction that empties the essence of their profession: freedom of information. The facts sought by the two categories of the stakeholders for their information, are in themselves external to magistrates and journalists. Legal information and media information are productions, constructions, whose sequences can be manipulated, from data collection or during processing.

The claims of this article are to contribute to the admissibility of the conflict paradigm in the study of relations between judges and journalists. The strategies of the actors are analyzed from the information and communication science field where research allows the consideration of another paradigm, that of mediation.

Historically, the predominance of the law over political institutions conferred to magistrates, in the collective imagination, such an ascendancy over other social body that judges use as replicas than from a consolidated executive power by the security apparatus of the military, or those from the legislature. The essence of the magistrate's profession is to ensure compliance by all to the rules of law enacted under the ideological premise in a democratic regime, only the law should stop the law. For journalists and the media, to emerge in the face of constituted powers, it must overcome political inertia. The magistrates, who by conservation reflex fight them with legal arguments, do not seem to be devoid of ulterior motives or strategic interests.

The National School of Administration and Magistracy (ENAM) was established on 1 July 1959, and the School of Journalism was established in 1970. But the question being debated here is not that of training to acquire a skill that one would like to apply and evaluate. This allows us to relativize the question of whether committing offenses is limited or not to the category of so-called journalists trained on the job or that of magistrates put under scrutiny by the Chancellery.

To the mockery of journalists, magistrates brandish a rigorous application of the law, even when it is proven that journalists are accountable for their acts twice as many times as judges. We are in the presence of two major players in institutions with very strong social inclusion and having both, a claim to act only for the universal ideal of truth and justice.

But truth and justice are not transcendental here. In these sub-groups of the judiciary and media information, they are built by the presentation of facts in the court. Between prosecution and defense, the most equipped, organized and skillful party wins, after the judge has assessed the evidence presented by the protagonists. The empirical observation of these relations is corroborated by the sociology of media in Cameroon and the mobilization of peripheral players, allies and each other's opponents.

Journalists of CRTV and Cameroon Tribune which are public service corporations and state organs, however, benefit a priori of a presumption of competence before the judges which is justified on first sight by the fact that these journalists a priori of a presumption of competence before the judges which is justified on first sight by the fact that these journalists lean on the position power against the decriminalization of press offenses. Magistrates and journalists clash, under the arbitration of a third pole, that of the Executive. This triadic game, par excellence, of social interaction, offers the ground for a triple and reversible manipulation.

There exists a discourse of judges on journalists within doctrine, in jurisprudence and through public speaking. And there is also a discourse of journalists on the judiciary, mainly used in the media and supported by activists from the civil society.

This demonstrates the existence of direct or deferred exchanges that permits the study of the content of their proclamations and alternately perception of their relations with each other-the epistemological relationship between information and communication (science of the study of the meaning of discourse) and mobilization of actors, which necessarily exists prior to information (Bougnoux, 1998). The actors' strategies reveal their intentions and ultimately the ideology of their respective professions. Discourses are a set of socially or ideologically marked statements historically dated and have a value for established communities.

Cultural anthropology and social psychology certainly throws move light on the hatred of the local actors' vis-à-vis those who dare reveal their turpitude. But we grasp them at the interstices of law, communication science and sociology, political science where territory and concepts are explicitly defined and codified. 


\subsubsection{Problematization}

The social problem of this relationship is that of a double disrespect, first, the apparent harassment by the judges of journalists, who are innocent victims persecuted by an essentially repressive judiciary; then that of irascible journalists who challenge the magistrates that no one dares to attack. The strategies used by these actors include open and hidden aspects that disturb the readability of the social game.

The scientific problem is that of the demarcation of the territories without fully distinct borders. The concept of territory retains the original idea of physical geographical space, territorial or air, as element of determining the state in international public law. The nation-state designates indeed a human community; and the territory bounded by borders, is one of its hardware components and at the same time a dispatcher of skills.

According to this metaphor, a territory, psychologically speaking, means a domain of definition of intellectual competence, a sphere reserved for the personal and intimate radiation of individual or collective actors. It refers to organizations where agents or actors interact to build a given social reality. The territory is finally as area of interest, a field of defined specific interest to the generality. It is a place of express transversal problematic issues, scientifically, in the sociology of territories or urban sociology, for example.

The relationship between journalists and judges show, as in states where problematic border flows are the sign of identity crises, the conflicting tensions that exist (Lewis, 1956, 1984). What is at stake here is a conflict. That is to say clashes between collective actors on values, status, power or scarce resources and in which the objective is to neutralize each protagonist, weaken or eliminate their rivals. It is first of all a social interaction revealing the antagonistic interests, and therefore, the hostile behavior of actors against each other.

The second problem is that of the discourse on the independence of judges or of the judiciary in the democratic ideal of balance of powers. This issue will be the subject of a particular study in the subsequent articles. We shall develop more hereon the first problem, that of border demarcation. Why, is it that magistrates and journalists who do not have the same occupations, compete with such determination?

If we accept that this is just a conflict for the monopoly of the dissemination of judicial information, so, who between the journalist and the magistrate in the exercise of his profession, can determine in advance the use of the facts that later will return to a judicial investigation, and therefore, proscribe or permit the partial or total distribution of information relating to these facts?

Research questions

1) In what way can one of the camps, by itself, establish and impose non-consensual operating rules on the other?

2) This conflict, is it only an allocation conflict or a conflict of jurisdiction and what are its implications?

3) How can the overall game be interpreted and explained?

The research hypotheses

1) Conflict zones appear to be those where there is interference or trespassing. Socio-professional boundaries therefore have no formal bounded areas, as magistrates and journalists feel they have a right to claim.

2) The magistrates have, in relation to journalists, the advantage of constituted power over institutionalized power.

Executive power is the determinant instance around which a triadic game is played, and in which we see just judges and journalists.

3) The actors sometimes have encrypted strategies, and sometimes have open strategies whish, indicate that the conflict has an alibi at the origin. The ultimate challenge is concealed by socio-political elite unwilling to strengthen the power of the media and journalists, which dominates social cadet in an exacerbated system of patrimonialism.

From these hypotheses, the first one is verified in this introductory article that establishes the general framework of the study objective and presents the problem. The other two hypotheses are verified and eventually validated in the second article, on a fully operational and decrypting all data collected from the field where the game between judges and journalists is observed.

\subsection{Research Methodology}

Our methodology shows the means, techniques and tools for the collection of field data, paradigms convened in demonstrations or the administration of evidence and the process of validating our assumptions.

\subsubsection{Methodological Tools}

We use a partial and transversal method to enlarge a part of the reality studied, in order to observe the phenomenon better. Less salient aspects are mentioned and temporarily excluded. They will be considered in a later 
study. Thomas ESSONO and I (Nguegan, 1996) are using participatory observation and knowledge inherited from professional practice as political analysts at the State Radio and Television, in a cumulative period between 1984 and 2008, during which we have observed the game from within, even live some friction with magistrates. We question the upstream logic.

\subsubsection{Paradigms Used}

Four main paradigms are used in this section of methodology. These are: actionalism, mediation and structuring power of media discourse; ethnomethodology and French discourse analysis. The symbolic interactionism and ethno methodological analysis are used because they enable us to show the exchanges between actors considered in their relationship to the executive power.

To understand and explain the activity, cohesion and social balance, interactionists propose paradigms and theories which are different from these functionalists. The reasons why individuals let others decide in their stead, and that despite explicit crises, there will be no explosion or social implosion are due the paradigms of exchanges, hence "interactionism", the inevitable contact among individuals, and the meaning that these individuals themselves place in these exchanges hence qualifier "symbolic" (Boudon, 1977; Touraine, 1965).

The social fact is a constructed process that the researcher captures and restores through direct observation (Mead, 1934).

Social life is thus a kind of theater where everyone plays roles, and pretends to take seriously the role of other actors (Goffman, 1959).

In the basic principles, it is always necessary to combine overt forms and covert forms of behavior: interactions and symbols (Gagnon \& Hebert, 2000). The researcher must, each time, highlight the views of stakeholders and bring symbols to the particular context of the actor; uphold the direct observation taking into account the conditions of the interaction. The re-visitation of these principles shows that they define ethnomethodology and allows us to consider both the theoretical and methodological framework.

Indexicality, reflexivity and practical common knowledge are then used to highlight the agonal character of the conflict.

\subsubsection{Verification of Hypotheses}

Ethnomethodology is the description of semantic fields as it occurs in a specific social context (Garfinkel, 2007). It favors the views of those involved in the construction of a social reality and the historical or psychological social contexts in which these actors are taken, following the example of the conflict between magistrates and journalists. The members of each society and therefore give meaning to the social order.

We should be attentive to the actions observed on the surface and distinguish the logic that guides these actions in depth (Gumperz, 1989; Schegloff, 2007). This model designed in linguistics to analyze verbal interactions, is applicable in communication when added to the model of mediation.

In the interpretative and explanatory framework we use, by resonance, explanations and writings of academics, communication specialists and those of the Law. This mechanism shows the players in their structural opposition, not grouped, as in focus groups. Since we are not working on opinions, we do not do samplings. We work on representations. Interviews are more appropriate. The study is qualitative. The actors are presented in a way those maps out the two main camps in conflict.

It implies thenceforth to demonstrate that the conflict here has an alibi origin and that at the second degree, behind the duality between the primacy of law and the established power of the media, (organized power) there is actually, the conflict of interest, a clash for the control of resources that only the Executive provides.

\subsection{Findings}

The construction of the scientific objective of the study permits, at the same time to present and analyze environmental data and the structuring of the actors involved, and to establish that the relationships between judges and journalists can be eligible for an ethnomethodological approach in Cameroon.

Indexicality is stated, in its principle, to express the dimension of self-identification which determines the speech of each group of actors on itself. Reflexivity, in its principle, expresses the hetero identification dimension, what others think or say about opponents. These elements of the socio professional profiling of the actors involved will be formally documented in the next article to support the evidence of the existence of the conflict. 
But they are already considered here in the construction of the objective, and they allow us to verify and validate the first research hypothesis. The socio-professional boundaries present areas which are not formally demarcated between magistrates and journalists.

Each territory is therefore trying to uphold its legitimacy, not on all the skills of the competitor but on this pivotal platform or segment of human rights. In this confrontation for marking territories, judicial information meets media information in the search for facts, their sequencing, their interpretation, the release of some information which is judged premature by some magistrates, the effective judgement of detainers justice done or not, on behalf of the people (Eyike \& Youssoufa, 2004). It is the untraced part of the delimitations of the socio-professional territories between journalists and magistrates.

By including in the Constitutional provisions the important work of journalists in the flow of information and respect for human rights, the State of Cameroon would formally confine the territories of journalists and that of the judges, territories in which each side feels entitled to claim a monopoly of jurisdiction.

The ideal society of freedom and justice is traditionally thought by installing, in the States, the judiciary as the guarantor of the rights and duties of citizens. This power is embodied by judges and lawyers who act under habeas corpus. Article 10 of the Universal Declaration of Human Rights proclaims the supremacy of the courts in these terms:

"Everyone is entitled in full equality to a fair and public hearing by an independent and impartial tribunal, in the determination of his rights and obligations or the truths of any criminal charge against him”.

It does not give the media and their journalists an article with equal strength to that of Article 10 of the Declaration text. The paradigm of conflict is therefore an interpretative register which permits us to use the theory of untraced territories for modelling.

It is a conflict felt by intuition at the beginning like a conflict of allocation or a conflict of competence of which the alibi origin offers a variety of reading material for modern and post modern societies.

\section{Conclusions}

If the regulatory instruments of international life that are contained in these texts constitute the source from which the magistrates and journalists draw their philosophy of action, it is the States' responsibility in their national laws to give substance facilities consequences of arbitration that harmonize wanting to live together.

This study assumes, at the same time, the notion of the interactionist and that of the system agent, used by systemists, because the parties to the conflict bring together alternate identities for themselves and for the others (Dubar, Tripier, \& Boussard, 2011). These positions emphasize at the same time the significance of individual characteristics with the methods of creating one's self-psychology, and collective characteristics better expressed by sociology. It ultimately allows us to express social symbolism:

"A form of language, a substitute activity or compensation, a medium of exchange of values, a system of relationships between individuals, attributing the same meaning to things, to constitute a community..." (Riviere, 1988).

Our research, organized in a series of articles, brought to completion, through the interpretative model, is expected to verify whether we are, in Cameroon, in the presence or absence of an open society, the dominant discourse society.

\section{References}

Boudon, R. (1977). Perverse Effects and Social Order. Paris: Presses Universitaires de France.

Bourdieu, P. (1980). The Distinction: A Social Critique of the Judgement. Paris: Minuit.

Boyomo, A. L. C. (1996). The Construction of the Identity of the Journalist. Polis, Cameroon Political Science Review, Political Identity and Democratization in Cameroon, 1, 111-128.

Boyomo, A. L. C. (1999). Media and Democracy in Cameroon: An Ethno Methodological Approach. Paris: Karthala.

Cabin, P. (2000). The Rise of Interactionist Sociology. Auxerre: Editions Sciences Humaines.

Dubar, C., Tripier, P., \& Boussard, V. (2011). Sociology of Professions (3rd ed.). Paris: Armand Colin.

Ebert, F. F. (1993). The Role of Media in the Democratic Process in Cameroon. Yaoundé: Friedrich Ebert Fondation.

Eyike, V., \& Youssoufa, B. (2004). The Criminal Litigation of Press and Audiovisual Communication in Cameroon. Yaoundé: Editions St Paul.

Freund, J. (2003). The Essence of Politics. Dalloz. 
Gagnon, M., \& Hebert, D. (2000). Seeking Sciences: Introduction to Epistemology. Montréal: Fides.

Garfinkel, H. (2007). Research in Ethnomethodology. Paris: PUF

Goffman, E. (1959). The Presentation of Self in Everyday Life. Edinburg: Anchor Books

Gumperz, J. (1989). Start a Conversation. Introduction to Interactional Sociolinguistics. Paris: Les Editions de Minuit.

Habermas, J. (1981). The Theory of Communication Action. Paris: Fayard

Lester, K. (1980). A Primer in Ethno Methodology. New York: Oxford University Press.

Mattelart, A., \& Mattelart, M. (2010). History of Communication Theories. Paris: Ed. La Découverte

Mead, G. H. (1934). Mind, Self and Society. Chicago, IL: University of Chicago Press.

Moscovici, S., \& Vignaux, G. (2000). Social Representations: Explorations in Social Psychology. Cambridge, UK: Polity Press

Nguegan, J. F. (1996). Professional Journalists and Institutional Communicators in Cameroon: Conflict of Competence or Conflict of Interest. Dissertation of Specialization in Political Analysis and Public Relations. Yaoundé: DSSTIC.

Riviere, C. (1988). The Political Liturgies. Paris: PUF.

Schegloff, E. A. (2007). Sequence Organization in Interaction: A Primer Conversation Analysis Volume 1. Cambridge, UK and New York: Cambridge University Press.

Tourain, A. (1965). Sociology of Action. Paris: Seuil. 